\title{
Quelling Public Fears About Guillain-Barré Syndrome and COVID-19 Vaccination
}

Dennis Bourdette, MD, and Joep Killestein, MD, PhD

Neurology ${ }^{\circledR}$ 2021;96:1021-1022. doi:10.1212/WNL.0000000000011882

\author{
Correspondence \\ Dr. Killestein \\ j.killestein@ \\ amsterdamumc.nl
}

\section{RELATED ARTICLE}

The only thing we have to fear is fear itself... which paralyzes needed efforts to convert retreat into advance.

$$
\text { _President Franklin Roosevelt, 1933, first inaugural speech }
$$

In late 2020, after nearly a year of fighting the severe acute respiratory syndrome coronavirus 2 (SARS-CoV-2) pandemic with masks and isolation, the first vaccines for the viral infection became available. These miracles of biotechnology offer the hope of ending the pandemic once manufacturing and distribution problems are resolved. By vaccinating $70 \%$ to $90 \%$ of the population, we can achieve herd immunity and end the pandemic. Unfortunately, many people are resistant to being vaccinated. A recent poll found that $20 \%$ of Americans say they will not be vaccinated unless it is forced on them, and $20 \%$ say they remain hesitant about being vaccinated because of fears about safety. ${ }^{1}$ Resistance to vaccination in Europe is comparable. ${ }^{2}$ A recent questionnaire study emphasizes the potential of physicians to increase willingness to get vaccinated by $>20 \%$. $^{2}$ The number of people who are hesitant to receive the coronavirus disease 2019 (COVID-19) vaccine is declining, but that trend could easily shift if potential concerning side effects lead to more fear.

In this issue of Neurology $y^{\circledR}$, Márquez Loza et al. ${ }^{3}$ present the case of a patient with Guillain-Barre syndrome (GBS) after COVID-19 vaccination. The patient developed typical GBS 10 days after receiving a recombinant, replication-incompetent adenovirus vector vaccine (Ad26.COV2.S, Johnson\&Johnson) as part of A Study of Ad26.COV2.S for the Prevention of SARS-CoV-2Mediated COVID-19 in Adult Participants (ENSEMBLE) trial (NCT04505722). The patient recovered after treatment with IV immunoglobulins. Importantly, GBS also occurred in a participant in the trial who received placebo. The authors emphasize that the temporal association of the GBS with the COVID-19 vaccination does not establish causation. They also appropriately point out that epidemiologic studies will be required to determine whether COVID-19 vaccination increases the risk of GBS above background rates. Given that the annual incidence of GBS is $\approx 10$ to 20 cases per 1 million among adults ${ }^{4}$ and hundreds of millions of people are to be vaccinated in North America and Europe, and hopefully billions worldwide, many cases of GBS will occur in temporal relationship to vaccination coincidentally. Indeed, a second case of GBS in association with the mRNA Pfizer COVID-19 vaccination was reported in February 2021..$^{5}$ Reports of GBS after COVID-19 vaccination risk raising fears about the safety of the vaccines, particularly among those who are hesitant or fearful about being vaccinated.

While the association of viral infections with GBS has long been recognized, whether vaccinations can increase the risk of GBS is less certain. Despite this uncertainty, the association of GBS with 1 vaccine contributed to the collapse of a national immunization program. ${ }^{6}$ Because of concerns about the possibility of an HINI influenza pandemic, in 1976, the US government embarked on a national program to immunize large numbers of the population. Ultimately, $>40$ million people received the H1N1 vaccine. Reports of cases of GBS in association with the
Guillain-Barré Syndrome in the Placebo and Active Arms of a COVID-19 Vaccine Clinical Trial: Temporal Associations Do Not Imply Causality Page 1052

MORE ONLINE

\section{COVID-19 Resources}

For the latest articles, invited commentaries, and blogs from physicians around the world

NPub.org/COVID19

From the Department of Neurology (D.B.), Oregon Health \& Science University, Portland; and Amsterdam UMC (J.K.), Vrije Universiteit Amsterdam, Department of Neurology, MS Center Amsterdam, Amsterdam Neuroscience, the Netherlands.

Go to Neurology.org/N for full disclosures. Funding information and disclosures deemed relevant by the authors, if any, are provided at the end of the article. 
vaccine began to appear in the fall of 1976 and were widely reported in the media. This led to concerns among the public about the safety of the vaccine. The association of GBS with the vaccine, coupled with evidence that a pandemic of influenza was not materializing, led to the termination of the vaccination program in December 1976. Subsequent epidemiologic studies suggested that the H1N1 influenza vaccine may have increased the number of cases of GBS by $\approx 1$ per 1 million on a background incidence of 10 to 20 cases per 1 million. Had the pandemic occurred, it is possible that fear of GBS may have seriously affected acceptance of the vaccine. Today, we have a pandemic, and we do not want fears arising among the public over the possibility that COVID-19 vaccines are causing GBS.

The enormous global impact of the COVID-19 pandemic has led to fast-tracked development of vaccines. ${ }^{7-10}$ This accelerated development, combined with the importance of a successful campaign in terms of societal impact, obviously led to extensive and critical monitoring of possible safety issues. During the ongoing worldwide vaccination plan, numerous adverse events after vaccination will be reported. In the majority, these will be without evidence of causality. However, it is important to maintain vigilant and complete reporting, and transparency will be an important pillar of a successful worldwide vaccination strategy. Therefore, neurologists should report cases of GBS and other autoimmune diseases occurring within 6 to 8 weeks after a COVID-19 vaccination even if causation is not suspected.

The potential of vaccines to possibly trigger GBS and other autoimmune neurologic syndromes may increase unwillingness to get vaccinated. There is consensus, however, that the benefits of recommended vaccinations outweigh possible risks, even of GBS and other autoimmune diseases. Vaccination prevents infections, which can be life-threatening, and the infection being prevented may also trigger GBS or other autoimmune diseases. Given the severity of COVID-19, we emphasize that in general all adults should be vaccinated against COVID-19.

Neurologists should be prepared to address concerns expressed by their patients and others when reports of GBS temporally associated with COVID-19 vaccines appear in the news and online. Our position should be that such associations are most likely coincidental and that it is unlikely that
COVID-19 vaccination causes GBS. We should also provide reassurances that there is ongoing monitoring of serious health problems, including GBS, occurring after COVID-19 vaccinations. Finally, we should emphasize that preventing COVID-19 with its proven risks of serious consequences outweighs any theoretical risks of GBS after vaccination. We must do everything that we can to assuage fears that the public might have about COVID-19 vaccination. Only through a successful international vaccination program will we end this pandemic.

\section{Study Funding}

No targeted funding reported.

\section{Disclosure}

D. Bourdette has received consultation fees from Magellan Health and Best Doctors, has a research grant from the National MS Society, and has founder stock in Autobahn Therapeutics. J. Killestein has speaking relationships with Merck, Biogen, TEVA, Sanofi, Genzyme, Roche, and Novartis. Amsterdam UMC, location VUmc, MS Center Amsterdam has received financial support for research activities from Merck, Celgene, Biogen, GlaxoSmithKline, Roche, Teva, Sanofi, Genzyme, and Novartis. Go to Neurology.org/ $\mathrm{N}$ for full disclosures.

\section{References}

1. Guidry JPD, Laestadius LI, Vraga EK, et al. Willingness to get the COVID-19 vaccine with and without emergency use authorization. Am J Infect Control. 2021;49(2): 137-142.

2. Boekel L, Hooijberg F, van Kempen ZLE, et al. Perspective of patients with autoimmune diseases on COVID-19 vaccination. Lancet Rheumatol. Epub 2021 Feb 22.

3. Márquez Loza AM, Holroyd KB, Johnson SA, Pilgrim DM, Amato AA. Guillain-Barré syndrome in the placebo and active arms of a COVID-19 vaccine clinical trial: temporal associations do not imply causality. Neurology. 2021;96(22):e1052-e1054.

4. Lunn MP, Cornblath DR, Jacobs BC, et al. COVID-19 vaccine and Guillain-Barre syndrome: let's not leap to associations. Brain. 2021;144(2):357-360.

5. Waheed S, Bayas A, Hindi F, et al. Neurological complications of COVID-19: Guillain-Barre syndrome following Pfizer COVID-19 vaccine. Cureus. 2021;13(2): e13426.

6. Spencer DJ, Millar JD. Reflections on the 1976 swine flu vaccination program. Emerg Infect Dis. 2006;12(1):29-33.

7. Voysey M, Clemens SAC, Madhi SA, et al. Safety and efficacy of the ChAdOx1 $\mathrm{nCoV}-19$ vaccine (AZD1222) against SARS-CoV-2: an interim analysis of four randomised controlled trials in Brazil, South Africa, and the UK. Lancet. 2021; 397(10269):99-111.

8. Polack FP, Thomas SJ, Kitchin N, et al. Safety and efficacy of the BNT162b2 mRNA COVID-19 vaccine. N Engl J Med. 2020;383:2603-2615.

9. Baden LR, El Sahly HM, Essink B, et al. Efficacy and safety of the mRNA-1273 SARSCoV-2 vaccine. N Engl J Med. 2021;384(5):403-416.

10. Sadoff J, Le Gars M, Shukarev G, et al. Interim results of a phase 1-2a trial of Ad26.COV2.S Covid-19 vaccine. N Engl J Med. Epub 2021 Jan 13. 


\section{Neurology}

\section{Quelling Public Fears About Guillain-Barré Syndrome and COVID-19 Vaccination Dennis Bourdette and Joep Killestein}

Neurology 2021;96;1021-1022 Published Online before print April 6, 2021

DOI 10.1212/WNL.0000000000011882

\section{This information is current as of April 6, 2021}

\section{Updated Information \&} Services

References

Citations

Subspecialty Collections

Permissions \& Licensing

Reprints including high resolution figures, can be found at: http://n.neurology.org/content/96/22/1021.full

This article cites 8 articles, 0 of which you can access for free at: http://n.neurology.org/content/96/22/1021.full\#ref-list-1

This article has been cited by 1 HighWire-hosted articles: http://n.neurology.org/content/96/22/1021.full\#\#otherarticles

This article, along with others on similar topics, appears in the following collection(s):

Autoimmune diseases

http://n.neurology.org/cgi/collection/autoimmune_diseases COVID-19

http://n.neurology.org/cgi/collection/covid_19

Guillain-Barre syndrome

http://n.neurology.org/cgi/collection/guillainbarre_syndrome

Information about reproducing this article in parts (figures,tables) or in its entirety can be found online at:

http://www.neurology.org/about/about_the_journal\#permissions

Information about ordering reprints can be found online:

http://n.neurology.org/subscribers/advertise

Neurology ${ }^{\circledR}$ is the official journal of the American Academy of Neurology. Published continuously since 1951, it is now a weekly with 48 issues per year. Copyright (O) 2021 American Academy of Neurology. All rights reserved. Print ISSN: 0028-3878. Online ISSN: 1526-632X.

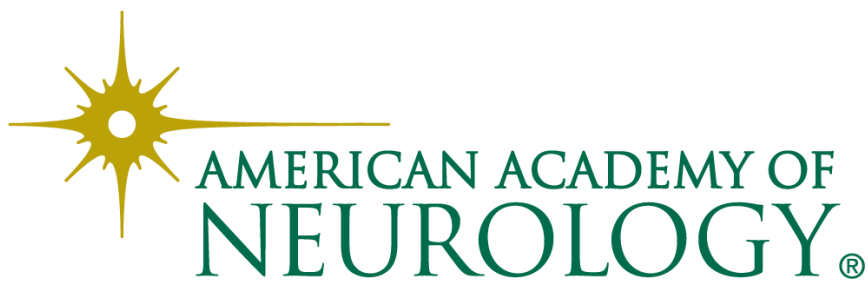

